\title{
Zasmidium persicae comb. nov., a new leaf spotting hyphomycete from Laos
}

\author{
Thapboualy $\mathbf{P}^{1}$, Souvannasane $\mathbf{T}^{2}$, Phengsintham $\mathbf{P}^{2}$ and Karunarathna $S C^{3}$ \\ ${ }^{1}$ Biology Department, Champasak University, Lao PDR \\ ${ }^{2}$ Biology Department, National University of Lao PDR \\ ${ }^{3}$ Key Laboratory for Plant Diversity and Biogeography of East Asia, Kunming Institute of Botany, Chinese Academy of \\ Sciences, 132 Lanhei Road, Kunming 650201, China
}

Thapboualy P, Souvannasane T, Phengsintham P, Karunarathna SC 2020 - Zasmidium persicae comb. nov., a new leaf spotting hyphomycete from Laos. Studies in Fungi 5(1), 353-357, Doi 10.5943/sif/5/1/16

\begin{abstract}
Comprehensive examination of cercosporoid leaf-spotting hyphomycetes was carried out in the southern areas of Laos. During this study, a species of Stenella was recorded for the first time from Laos, and according to current taxonomic concepts, this species is transferred to the genus Zasmidium.
\end{abstract}

Key words - anamorphic fungi - cercosporoid hyphomycetes - new record - South East Asia Stenella persicae - taxonomy

\section{Introduction}

Stenella was described by Sydow (1930) and recognized by Ellis (1971, 1976), who reduced Biharia Thirum. \& Mishra (Thirumalachar \& Mishra 1953, Misha et al. 1999) to synonymy with this genus. Deighton (1979) followed this concept of Stenella and differentiated it from Mycovellosiella based on the formation of verruculose superficial hyphae and usually roughwalled, catenate conidia. Up to the present time about 150 species were recorded. The main characters of Stenella are verruculose, superficial secondary mycelium and conidia amero- to scolecosporous, mostly verruculose. However, the oldest name Zasmidium is available for the whole complex (Crous \& Braun 2003). Therefore, all Stenella species need to be reassessed, either by molecular methods or by detailed examination of the conidiogenous loci or scar structure. Zasmidium species from Laos were first described by Phengsintham et al. (2009, 2010, 2012) and eight species of Zasmidium have been recorded from Laos (Phengsintham et al. 2013). In this paper we provide a new record of a Zasmidium species from Laos.

\section{Materials \& Methods}

Marcroscopic characteristics were observed using a stereoscope to check leaf spots and colonies/caespituli. Microscopic characters were observed using a compound microscope.

Where sufficient material was available, 30 measurements were made of mycelia and asexual reproductive structures. The average of the size of each component was calculated by using the formula:

$$
\left(\bar{X}=\frac{\sum M}{n} \mu \mathrm{m}\right),
$$


Notes: $\bar{X}=$ is an average of the size of each component

$\mathrm{m}=$ is a size of each component

$\mathrm{n}=$ is a number of components

The species of cercosporoid hyphomycetes from Laos were determined on the basis of the current relevant taxonomic publications cited in the references.

Dried specimens were prepared and stored in the herbaria of the Biology Department, Faculty of Natural Sciences, National University of Laos and the Biology Department, Faculty of Sciences, Champasack University of Laos.

\section{Taxonomy}

Zasmidium persicae (T. Yokoy. \& Nasu) Thapboualy, Souvannasane, Phengsintham \& Karunarathna comb. nov.

Figs 1-2

MycoBank number: MB 832090

Basionym - Stenella persicae T. Yokoy. \& Nasu, Mycoscience 41(1): 92 (2000).

Description - Leaf spots circular to irregular, 0.1-1.6 $\times 0.1-1.4 \mathrm{~mm}$ diam. $(\bar{x}=0.3 \times 0.2 \mathrm{~mm}$, $\mathrm{n}=30$ ), brown to dark brown in the center, margin yellow-brown. Caespituli/colonies amphigenous, small, scattered, brown. Mycelium internal and external; external hyphae branched, 1-4 $\mu \mathrm{m}$ wide $(\bar{X}=3.3 \mu \mathrm{m}, \mathrm{n}=8)$, septate, constricted at the septa, distance between septa $5-30 \mu \mathrm{m}$ $(\bar{X}=16.8 \mu \mathrm{m}, \mathrm{n}=8)$, pale olivaceous-brown, wall $0.3-0.5 \mu \mathrm{m}$ wide $(\bar{X}=0.39 \mu \mathrm{m}, \mathrm{n}=8)$, smooth or verruculose. Stromata lacking. Conidiophores solitary, borne on external hyphae, unbranched, cylindrical, $10-160 \times 2-6 \mu \mathrm{m}(\bar{x}=73.1 \times 4.3 \mu \mathrm{m}, \mathrm{n}=30), 1-10$-septate, distance between septa 4$45 \times 2-5 \mu \mathrm{m}(\bar{X}=30.3 \times 2.33 \mu \mathrm{m}, \mathrm{n}=30)$, brown to dark brown, wall $0.5-0.8 \mu \mathrm{m}$ wide $(\bar{x}=0.58$ $\mu \mathrm{m}, \mathrm{n}=30$ ), smooth, $0-2$ times geniculate; conidiogenous cells polyblastic, integrated, terminal or intercalary, $5-35 \times 1-4 \mu \mathrm{m}(\bar{x}=20.4 \times 2.1 \mu \mathrm{m}, \mathrm{n}=30)$, cylindrical, pale at the apex; conidiogenous loci small, conspicuous, subplanate to planate, $1-1.5 \mu \mathrm{m}$ wide $(\bar{x}=1.15 \mu \mathrm{m}, \mathrm{n}=$ 10), thickened, darkened. Conidia solitary or catenate sometimes subcylindrical, but mostly slightly obclavate, occasionally with lateral branchlets, straight or slightly curved to sinuous, 5-50 $\times 2-4$ $\mu \mathrm{m}(\bar{x}=23.4 \times 2.6 \mu \mathrm{m}, \mathrm{n}=30), 0-5$-septate, pale olivaceous, wall $0.3-0.5 \mu \mathrm{m}$ wide $(\bar{x}=0.36 \mu \mathrm{m}$, $\mathrm{n}=30$ ), smooth or finely verruculose, apex rounded or subtruncate, with a conspicuous hilum, base truncate, hila slightly thickened and darkened, $1-1.5 \mu \mathrm{m}$ wide $(\bar{X}=1.04 \mu \mathrm{m}, \mathrm{n}=30)$, wall of hila $0.5-0.8 \mu \mathrm{m}(\bar{x}=0.52 \mu \mathrm{m}, \mathrm{n}=30)$ thick .

Known host - Prunus persica (Rosaceae).

Known distribution - Japan, Laos and Taiwan.

Material examined - Champasack Province, Paksong District, Phou Ouy Village, on leaves of Prunus persica (Rosaceae), 12 October 2015, Phanomxay Thapboualy (CPS 05/2015); ibid., 26 November 2015, Phanomxay Thapboualy (CPS 30/2015).

\section{Discussion}

Stenella persicae was originally described as causing mould of peach fruits (Prunus persica var. vulgaris Maxim.) in Japan (Yokoyama \& Nasu 2000, Kirschner \& Chen 2007). Another species, Stenella anomoconis de Hoog \& Boekhout was described from Prunus sp.; it differs from S. persicae by longer (125-200 $\mu \mathrm{m}$ ) conidiophores and non-catenate conidia (Hoog et al. 1983).

The conidiophores and conidia of Stenella persicae as described by Yokoyama \& Nasu (2000) and of the Laos specimens are compared in Table 1, along with morphological details of $S$. anomoconis. The conidiophores of Zasmidium persicae from Lao collection has more varied septation (1-10 septa) compared to 3-8 septa from Japan. The Lao specimen was described directly from leaf spots of Prunus persica while from Japan it was described from a water agar culture. 
Table 1 Comparison of conidiophores and conidia of Zasmidium persicae and Stenella anomoconis from Prunus.

\begin{tabular}{|c|c|c|c|c|}
\hline & \multicolumn{2}{|l|}{ Conidiophores } & \multicolumn{2}{|l|}{ Conidia } \\
\hline & Length and width & Septation & Length and width & Septation \\
\hline $\begin{array}{l}\text { Stenella anomoconis } \\
\text { (Hoog et al. 1983) }\end{array}$ & $\begin{array}{l}125-200 \times 3.0-3.8 \\
\mu \mathrm{m}\end{array}$ & 3-12- septate & $\begin{array}{l}7.5-12.5 \times 2.8-4.0 \\
\mu \mathrm{m}\end{array}$ & 1-5-septate \\
\hline $\begin{array}{l}\text { Stenella persicae } \\
\text { (Yokoyama \& Nasu 2000) }\end{array}$ & $\begin{array}{l}(20-) 68-102(-111) \times \\
(3-) 3.5-4 \mu \mathrm{m}\end{array}$ & 3-8- septate & $\begin{array}{l}(4-) 9-34(-55) \times 2-4 \\
\mu \mathrm{m}\end{array}$ & 0-3-septate \\
\hline $\begin{array}{l}\text { Zasmidium persicae } \\
\text { (this paper) }\end{array}$ & $\begin{array}{l}10-160 \times 2-6 \mu \mathrm{m} \\
(\bar{x}=73.1 \times 4.3 \mu \mathrm{m})\end{array}$ & 1-10-septate & $\begin{array}{l}5-50 \times 2-4 \mu \mathrm{m}(\bar{x}= \\
23.4 \times 2.6 \mu \mathrm{m})\end{array}$ & 0-5-septate \\
\hline
\end{tabular}

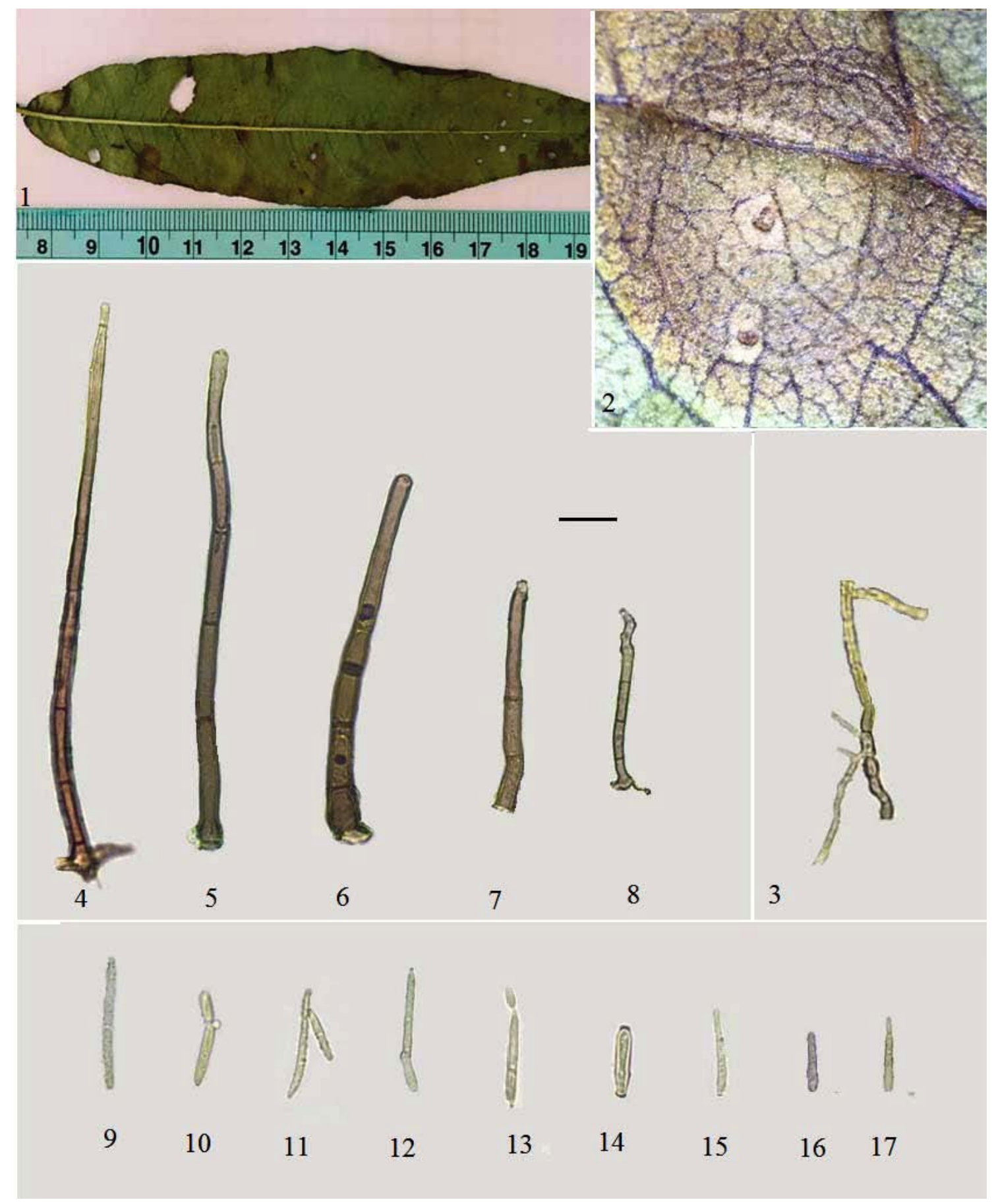

Fig. 1 - Zasmidium persicae on Prunus persica from leaf spots: 1 Leaf spots. 2 Caespituli. 3 Hyphae. 4-8 Conidiophores. 9-17 Conidia. Scale bars: 3-17 = $10 \mu \mathrm{m}$. 


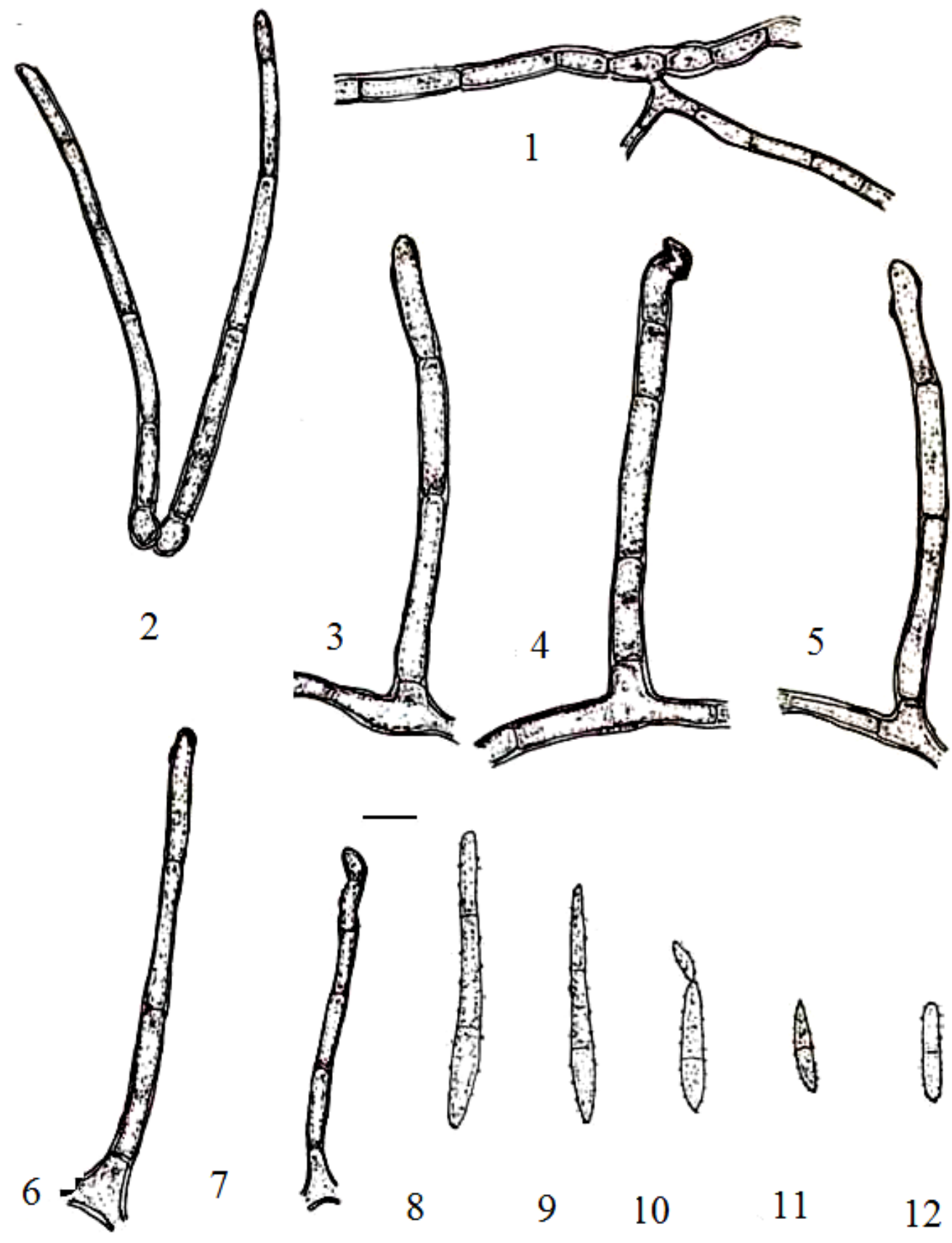

Fig. 2 - Zasmidium persicae on Prunus persica from leaf spots: Line drawing: 1 External mycelium. 2-7 Conidiophores. 8-12 Conidia. Scale bars: 1-12 = $10 \mu \mathrm{m}$.

\section{Acknowledgements}

The authors would like to thank the Champasack University of Laos for financial support. Special thanks also go to Prof. Braun for checking description and identification of the species.

\section{References}

Crous PW, Braun U. 2003 - Mycosphaerella and its anamorphs: 1. Names published in Cercospora and Passalora, CBS Biodiversity Series 1, 1-569.

Deighton FC. 1979 - Studies on Cercospora and allied genera. VII. New species and redispositions. Mycological Papers 144, 1-56. 
Ellis MB. 1971 - Dematiaceous hyphomycetes. Commonwealth Mycological Institute Kew, Surrey, England.

Ellis MB. 1976 - More dematiaceous hyphomycetes. Commonwealth Mycological Institute Kew, Surrey, England.

Hoog GS de, Rahman MA, Boekhout T. 1983 - Ramichloridium, Veronaea and Stenella: generic delimitation, new combinations and two new species. Transactions of the British Mycological Society 81: 485-490.

Kirschner R, Chen CJ. 2007 - Foliicolous hyphomycetes from Taiwan. Fungal Diversity 26: 219239.

Mishra S, Srivastava KK, Kamal. 1999 - Further additions to Stenella from India and Nepal. Mycological Research 103(3): 268-270.

Phengsintham P, Hyde KD, Braun U. 2009 - Cercospora and allied genera from Laos 1. Notes on Zasmidium (Stenella s.lat.). Cryptologie, Mycologie 30(3): 243-262.

Phengsintham P, Chukeatirote E, Abdelsalam KA, Hyde KD, Braun U. 2010 - Cercospora and allied genera from Laos 3. Cryptogamie, Mycologie 31(3): 305-322.

Phengsintham P, Chukeatirote E, McKenzie EHC, Moslem MA et al. 2012 - Fourteen new records of cercosporoids from Thailand. Maejo International Journal of Science and Technology, 6(1): 47-61.

Phengsintham P, Chukeatirote E, McKenzie EHC, Hyde KD, Braun U. 2013 - Monograph of cercosporoid fungi from Laos. Current Research in Environmental and Applied Mycology 3(1): 34-158.

Sydow H. 1930 - Stenella Syd. Annales Mycologici 28 (1-2): 205 (1930).

Thirumalachar MJ, Mishra JN. 1953 - Contribution to the study of fungi of Bihar, India - I. Sydowia 7(1-4): 29-83.

Yokoyama T, Nasu H. 2000 - Materials for the fungus flora of Japan (54). Stenella persicae, a new species from peach. Mycoscience 41: 91-93. 